\title{
MODERN APPROACHES TO THE ESSENCE AND FORMS OF PUBLIC ADMINISTRATION
}

\section{Svitlana Greben ${ }^{1}$, Iryna Mihus ${ }^{2}$}

${ }^{1}$ Ph.D. (Public Administration), State Audit Service of Ukraine, Kyiv, Ukraine, e-mail: cvetikus77@ukr.net, ORCID: https://orcid.org/0000-0002-0432-9132

${ }^{1}$ Doctor of Science (Economics), professor, "KROK" University, Kyiv, Ukraine, e-mail: irynamihus@gmail.com,ORCID: https://orcid.org/0000-0001-6939-9097

Reforming public life in Ukraine, increasing its competitiveness among other states certainly requires effective public administration. It is under these conditions that there is a need for a thorough scientific justification of the essence of public administration. At the same time, modern literature and practical experience of Ukraine and a home testify to the absence of a universally recognized concept of "public administration". It is interpreted through the content, essence, types of which it acquires and in which it functions. Sometimes scientists dedicate some types of state activities from others.

In particular, according to the concept of public administration by representatives of general sociological scientific directions of management is considered from its real content as a specific type of social activity aimed at systematic implementation of certain influence of people on the public system as a whole or on its individual levels, on the basis of knowledge and use of inherent system of objective patterns and trends, in order to ensure its functioning and achievement of the set goals [1].

In contrast to this concept in administrative and legal science, the concept of public administration is considered as an independent type of state activity, which has an organizing, executive-regulatory, bylaw nature, a special group of state bodies (officials) on the practical implementation of functions and tasks of the state in the process of everyday and direct leadership of economic, socio-cultural and administrative and political construction [1]. Another interpretation of these views of scientists on public administration is the consideration of this concept from a position of narrow and broad understanding.

Proponents of a narrow interpretation, among which the main place is occupied by I.O. Kresin and A.S. Anisimov, erect public administration to the organizational, executive and regulatory activities of the state bodies, which is carried out on the basis and for the purpose of implementation of laws and consists in the everyday practical performance of certain functions. Thus, according to this approach, the content of the subject of public administration is reduced to the framework of executive power. However, it is difficult to agree with this, since the state acts as the unity of all three branches of government, as a form of political organization of 
society as a whole, and withdrawal from the sphere of public administration on the basis of executive functions of civil servants, in fact, puts public administration on one stage with public service [2].

A striking example of a narrow understanding of public administration is also outlined in the book "Public Administration and Administrative Law in Modern Ukraine: Actual Problems of Reform". From the point of view of the authors, one of whom is V.B. Aveyanov, public administration is separated as a relatively independent activity of the state among others, such as legislative work of the councils of people's deputies of all levels, justice and prosecutorial supervision, etc. [3].

In the context of a narrow understanding of public administration, which in subjective terms approaches its broad understanding, is the implementation of public management of economic processes through two channels, namely: governmental and non-governmental structures [4]. This approach is outlined in the work "Reforming public administration in Ukraine: problems and prospects", author V.V. Tsvetkov. At the same time, as noted by the author, this design of public administration is flexible and has significant adaptation capabilities.

In view of this, the state administration in such a scientific view extends its subjectivity beyond the state apparatus with the possibility of forming mixed management structures - public-private or public-public. Under these conditions, public administration is considered primarily as administrative management, which is carried out by state and non-state bodies, and human rights and citizens remain out of consideration.

Thus, the main feature of the model of a narrow approach is the identifying of the sphere of public administration and the sphere of implementation of the executive power, the subjects of which are the bodies of this government of all levels. Therefore, this approach can be seen only as a form of instrumental definition of public administration.

At the same time, it should be noted that a narrow understanding of public administration is used not only in theory, but also in managerial practice. These postulates were introduced in the Concept of Administrative Reform in Ukraine, where public administration is defined as "the type of activity of the state, which consists in its management, that is, the organizing influence on those spheres and sectors of public life that require some interference of the state through the use of executive powers" [5].

At the same time, it is further noted that public administration is carried out outside the functioning of the executive branch, and due to this, the concept of "public administration" is wider than the concept of "executive power". As an example, the Concept defines cases of management at the level of state-owned 
enterprises, institutions and organizations. At the same time, such interpretation generates a number of issues that require further specification of this definition.

In particular, the use of the phrase "type of activity of the state" indicates the existence of other types of state activities that differ from management. As a result, the question arises whether public administration is different from other types of state activities. First of all, this issue is to define the boundaries of the public administration sector and the public life sector, where public administration is not considered. Another issue related to the first concerns the subjective aspect of public administration. After all, such a definition on the one hand states a wider scope of the concept of "public administration" compared to the concept of "executive power", on the other hand - the concept of "public administration system" clearly implies that the subjects of public administration are executive bodies and others are not mentioned [6].

Thus, according to the narrow understanding of public administration, the problems outlined cannot be solved. With this in mind, knowledge of the essence of public administration is possible due to the broad interpretation of this area of activity. Summarizing the concept of public administration through a "broad model", scientists interpret it as a purposeful, organizing and regulatory influence of the state (through the system of its bodies and officials) on the development of social processes, relations and activities of a person and a citizen.

This position is supported by L.P. Zerkin and V.G. Ignatov, who view public administration as a kind of social management, the species distinction of which is determined by a number of properties [7]. In particular, the state is a specific subject of managerial influence, and the basis of such influence is the powers. In this view, public administration is a way of exercising state power. In addition, the content of public administration is caused by the resolution of general affairs of citizens, coordination of their actions and protection of general interests. And the methods of implementation of this administration are the possibility of using organized coercion using specialized bodies.

Right in terms of narrow and broad understanding of public administration is the remarks of O.M. Bandurka [8], where public administration is understood as a certain kind of social activity in a broad and narrow sense. In a narrow sense - is the administrative, executive and regulatory activities of the state. From these positions, public administration is studied, in particular, administrative law. Its object is a legal form of public administration. In a broad sense - it is organized, orderly activities of the state, state regulation of various social (sometimes personal) relations through the activities of all branches of state power - legislative, executive, judicial, their bodies, civil servants. 
The purpose of public administration is the settlement and ordering of life and relations of the person, team, state and society, establishing their rational relationships through the use of state power [8]. Generalizing diversity of views on public administration should be considered as intraorganization activities of state bodies aimed at regulating social relations in certain spheres of public policy in order to satisfy all kinds of social relations.

Public administration is one of the main types of governance in society - social governance, which is primarily due to the peculiarity of the legal status of its main subject - the state, which extends its power to the whole society and even beyond. Taking into account the fact that tens of millions of people are involved in public administration, a huge number of government agencies and officials, it requires a variety of resources: material, financial, intellectual, information, etc. [9].

At the same time, the rights and freedoms of citizens are ensured and implemented in practice only if they are reliable protection [10]. The state, implementing the lawmaking function, establishes general rules (requirements, norms) of people's behavior in all spheres of public life, as well as ensures their compliance with the possibility of using state coercion. However, coercion is not the main, but an auxiliary factor in the ordering of social relations. The main priority of any democratic state should be to ensure the realization of rights, freedoms and legitimate interests of its population, serving it. In this regard, the system of public administration should be close to the needs and requests of ordinary people, controlled by the population, transparent and effective [11].

Therefore, it is necessary to pay attention to the expressed opinion of Y. P. Bytyak that the use of only strict options for managing social processes contradicts the given model of development of society, and the system itself no longer "allows" the state to interfere in all issues of governance and practical activity, as it was before Ukraine declared independence [1].

The essence of public administration is also determined by the fact that it is carried out, firstly, within the activities of executive authorities, namely during:

- realization of their powers on managed objects of external social (economic, social, etc.) environment;

- fulfillment by local state administrations of the powers of local selfgovernment bodies delegated by the relevant local councils, despite the fact that these powers do not originally belong to the executive authorities;

- management of higher executive authorities activities of lower bodies;

- management of the work of civil servants within the apparatus of each executive body [12].

Secondly, public administration is carried out outside the activities of executive authorities, namely: 
- inside the apparatuses of any other (except executive authorities) of public authorities - on the part of their managers regarding other officials (for example, in the parliamentary offices, courts, public prosecutor's offices, etc.);

- within state-owned enterprises, institutions and organizations - on the part of their administrations regarding the rest of the personnel;

- on the part of certain state-authorized entities in the process of managing state corporate rights;

- on the part of various advisory and advisory bodies formed by state bodies (for example, the President of Ukraine) in terms of the exercise of organizational and regulatory powers granted to them by other bodies, officials [12].

The signs of public administration, in the opinion of V.V. Tsvetkov, is that it is:

a socio-political phenomenon; the process of realization of state power, its external, materialized definition and does not exist outside it (it most completely characterizes the content of the government);

executive and regulatory activities that substantiate the executive appointment; bylaws, although endowed with power and regulatory competence,

as it is carried out in accordance with the laws and for their implementation [13]. According to M.P. Tkach, public administration is characterized by the following features:

conducted in those sectors requiring active state intervention;

the object of public administration is legislatively regulated social relations, and the goal is to achieve a legislatively defined level of ordering of social relations;

the final stage of public administration is control over the legality of the activities of the subjects of social relations and its expediency;

the exact list of functions of public administration is determined by the sphere of social relations, which are regulated by the relevant law;

carried out in the sphere of executive power; state administration for the implementation of laws is accompanied by intraorganization activities of state bodies [14].

Along with this, disclosure of the essence of public administration is not possible without expressing the functions to which it is directed. At the same time, it does not have a single scientific view on the classification of functions of public administration. Generalizing the main approaches to determining functions, we consider it appropriate to lay out their classification in this form (Fig. 1).

Taking into account the specifics of the parameters of the functions of public administration, the main characteristics are $[15,16,17,18,19,20]$ :

permanent - necessary for the state at all stages of its existence;

specific - determined by objective circumstances in certain countries (traditions, the presence of many nationalities, religions, remote or special territories, etc.); 
special - reflect the special content of individual influences, due to the diversity of many interacting components in the management (are implemented, as a rule, in certain spheres, industries or areas of public administration and are determined by the requests of management objects: economic, spiritual, etc.);

general - reflect the essence of public administration, its objectively necessary relationships and take place in almost any managerial interaction of public authorities with the objects of management.

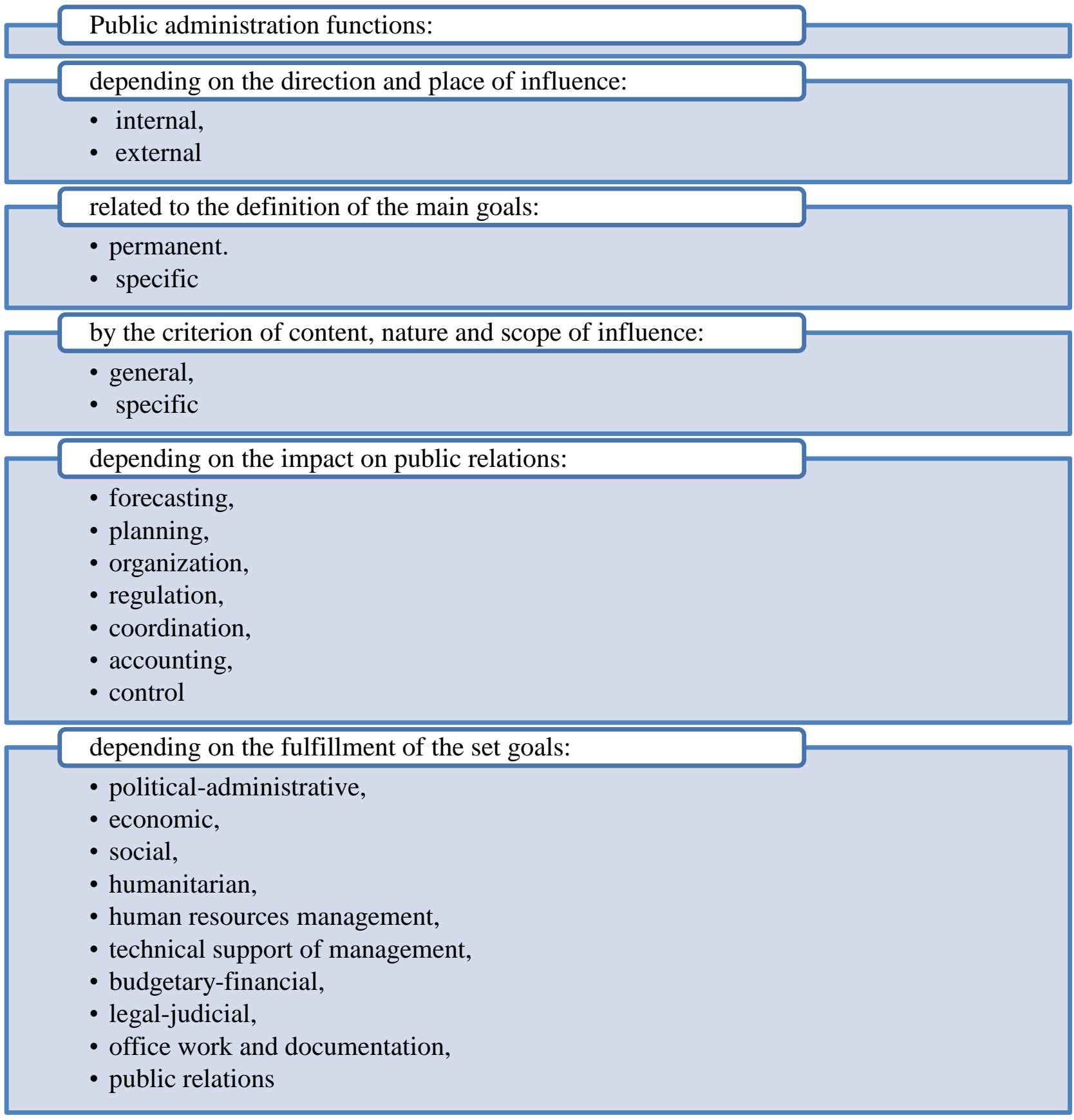

Fig. 1. Classification of functions of public administration

Source: compiled by the author on the basis of [15, 16, 17, 18, 19, 20] 
According to the position of D.I. Dzvinchuk, in character and sequence of actions, it is advisable to include the general functions of management: analysis, forecasting, planning, organization, regulation, work with personnel, accounting and control [16].

Along with this, supportive opinions of T.M. Kravtsova and G.V. Kalinichenko [17], due to the impact on social relations of forecasting, planning, organization, regulation, coordination, accounting (statistics) and control, it is advisable to distinguish both individual functions of public administration, determining that:

Forecasting - provides for the use of both experience accumulated in the past and current assumptions for the prediction of management processes and phenomena in the future, as well as solving problems that may face the subject of public administration;

Planning depends on defining the main goals and objectives set for public administration, and drawing up an action plan, developing programs to meet the tasks and objectives. It can be strategic (in determining long-term, strategic goals and means of their implementation) and current (defining everyday tasks and developing an action plan for their implementation). A striking example of the application of this function in public administration is the budget process;

The organization is connected with the creation of an effective organizational system in the form of management bodies, the main purpose of which is to perform the functions and tasks assigned to them; Regulation - achieving stability and improving the system of public administration. This function is important for providing processes for managing certain areas and achieving the tasks set [18];

Coordination - ensuring consistency of actions in the work of subjects of management of all levels, establishment of new ones, preservation and improvement of existing ties between them; Accounting (statistics) - consists in the collection, storage, processing, registration, systematization of data, which in turn come to public administration bodies and is necessary for the effectiveness of the activities of public administration bodies; Control - detection of shortcomings and their timely correction, by correcting the actions of public administration bodies through scheduled and unscheduled inspections, audits, surveys, etc.;

Internal - management in the middle of the state management system;

External - characterize directly the process of influence of public authorities on management objects;

Political and administrative - solving socially significant problems for the provision of services to the population: ensuring state sovereignty and defense capabilities, implementation of domestic and foreign policy, ensuring the rights and freedoms of man and citizen, regulation of demographic and migration processes, etc.; 
Economic - ensuring the functioning of the economic mechanism in accordance with the goals and priorities of the state economic policy: guarantee of economic security and independence, implementation of financial, pricing, investment and tax policy, etc.;

Social - solving problems to ensure vital needs: development and implementation of state programs for the development of social sphere, formation and implementation of measures to ensure health and hygiene of the population, regulation of labor relations between hired workers and employers, etc.;

Humanitarian - ensure achievement of the goals of public administration in the humanitarian sphere: development and implementation of state programs of general, technical, humanitarian education, ensuring the development of science, art, culture and sports, etc.;

Human Resources Management - development of the human resources system for the implementation of functions of public administration: the use of modern methods of personnel management, the formation of an effective recruitment system, measures to update the managerial elite, the introduction of mechanisms for personnel development, etc.;

Technical support of management - technical support in the performance of functions of public administration: formation of modern technical base of management influence, timely updating of technical means, development of new technologies, etc.;

Budget and financial - ensuring regulation of the budget process in the country;

Legal and judicial - ensuring compliance with decisions, regulatory documents of executive authorities to the current law of giving, legal norms;

Record keeping and documentation - ensuring documentation of management activities, organizational and methodological support of work with documents in structural subdivisions of subjects of public administration, etc.;

Public relations - ensuring transparency in the activities of the authority and protecting the interests of the state and the citizen in the world information space.

Consequently, the functions of public administration are the activities of state bodies to ensure the fulfillment of the tasks of public administration. At the same time, it should be noted that the highlighting of a certain function among other things will not ensure the effectiveness of the system of public administration and will not allow the subject of this administration (public authority) to provide vital needs of the facility of management (society).

In view of this, the main tasks of public administration, in our opinion, should be focused on: 
- optimization of the system of public administration in order to create an effective organization of public administration at both central and regional levels;

- proper personnel policy to ensure the effectiveness of public administration in various spheres of public life;

- ensuring the development of science for the introduction of innovations and effective development of the information system of public administration;

- sufficient level of financial support in the sphere of public administration; updating the legal framework on public administration;

- effective mechanism for combating corruption.

At the same time, the implementation of the tasks through the system of state bodies is carried out through the use of various forms of public administration. In each case, public authorities choose the form of management activity in relation to their competence and the peculiarities of the management object. In our opinion, it is advisable to summarize such forms of public administration (Table 1).

\section{Table 1. Forms of Public Administration}

\begin{tabular}{|l|l|}
\hline \multicolumn{1}{|c|}{$\begin{array}{c}\text { Forms of public } \\
\text { administration }\end{array}$} & \multicolumn{1}{c|}{ Components of public administration } \\
\hline $\begin{array}{l}\text { Publication of regulatory } \\
\text { acts of management }\end{array}$ & $\begin{array}{l}\text { fixing management decisions for the abnormality of management activities: } \\
\text { the procedure for conducting personal affairs of civil servants, typical } \\
\text { regulations of local state administrations, statutes, etc. }\end{array}$ \\
\hline $\begin{array}{l}\text { Conclusion of administrative } \\
\text { contracts }\end{array}$ & $\begin{array}{l}\text { registration of relations between other state and other entities in pursuance of } \\
\text { certain actions and measures }\end{array}$ \\
\hline $\begin{array}{l}\text { Carrying out legally } \\
\text { significant actions }\end{array}$ & $\begin{array}{l}\text { decisions based on laws or other bylaws and are aimed at certain legal } \\
\text { consequences: state registration; publication of official documents; licensing, } \\
\text { etc. }\end{array}$ \\
\hline Organizational activities & $\begin{array}{l}\text { holding meetings; development of methodological recommendations and } \\
\text { instructions; holding press conferences, etc. }\end{array}$ \\
\hline $\begin{array}{l}\text { Material and technical } \\
\text { operations }\end{array}$ & $\begin{array}{l}\text { ensuring proper document management system, analysis of information, } \\
\text { preparation of analytical and statistical data, organization of technical } \\
\text { support, etc. }\end{array}$ \\
\hline
\end{tabular}

Source: compiled by the author on the basis of [16]

The first three forms of public administration belong to the legal ones, because they have certain legal consequences, the latter two are not legal, because they do not cause such consequences.

The use of the delineated forms of public administration should be carried out using methods of public administration, which are defined as methods and techniques of analysis and evaluation of managerial situations, the use of legal and organizational forms, influence on the consciousness and behavior of people in managed social processes, relations and connections [16]. 
Methods of management activity, as noted by D.I. Dzvinchuk [16], are usually classified into two main groups:

- methods of functioning of state authorities and local self-government bodies;

- methods of ensuring the implementation of the goals and functions of public administration [21].

Methods of functioning of state authorities and local self-government bodies cover methods, techniques, actions (including officials involved in the processes of public administration), which are connected with the preparation and implementation of management decisions, as well as the implementation of legal and organizational state-management activities. They ensure consistency, predeterminedness, validity and efficiency of all management functions, organizational structures, forms, methods and stages of management activity [22].

The methods of management activity include organizational, administrative, economic, socio-psychological and other methods [23].

Methods for ensuring the implementation of the goals and functions of public administration are techniques, methods, operations of stimulation, activation and direction of human activity by state authorities or local self-government bodies and their officials [22].

Thus, summing up the above, in our opinion, public administration is a multifaceted concept, the nature of which depends on the specific circumstances, and which is implemented at the level of "object - subject" of management, and the result depends on the correctness of the tasks and the distribution of available resources (human, material and information).

\section{References:}

1. Bytyak Y.P.\&etc. (2007). Administrative law of Ukraine : textbook. 544 p.

2. Ansimova A. S. (2001). Public administration and public service in a transforming society. 278 p.

3. Aveyanov V. B. (1999). Public administration and administrative law in modern Ukraine: actual problems of reform: monograph. $156 \mathrm{p}$.

4. Tsvetkov V. V. (1998). Reforming public administration in Ukraine: problems and prospects. 364 p.

5. Concept of administrative reform in Ukraine from June 11, 1999 URL : https://zakon.rada.gov.ua/laws/show/810/98.

6. Jafarova M. (2005). Regarding the definition of "public administration". Law and security. No 1 (4/1). p. 26-29.

7. Zerkin A.P., Ignatov V.G. (2000). Basics of the theory of public administration: taught. Guide. 453 p.

8. Bandurka O. M. (1997). Fundamentals of management in internal affairs bodies. 567 p.

9. Pylypyshyn V.P. Concepts and main features of public administration. Law science and practice. 2011. No 2. P. 10-14.

10. Romanenko E. O. (2010). State policy in the field of human rights and freedoms. Public administration: improvement and development. No 1. URL : http://nbuv.gov.ua/UJRN/Duur 201018 .

11. Lyakhovych G.I. (2009). Regarding modern understanding of the essence and peculiarities of public administration in the state. KhNUS Herald. No 3 (46). P. 129-136.

12. Avelyanov V. B. (2003). State Administration: problems of administrative and legal theory and practice. $384 \mathrm{p}$. 
13. Tsvetkov V. V. (2007). Democracy and public administration: theory, methodology, practice: monograph. $336 \mathrm{p}$.

14. Weaver M.P. (2012). Problems of defining the concept of public administration. Legal Bulletin of the Ukrainian Academy of Banking.. No 1 (6). P. 60-65.

15. Atamanchuk G. V. (2004). Theory of State Administration: lectern course. 584 p.

16. Dzvinchuk D.I. (2012). Public Administration: course of lectures. 616 p.

17. Kravtsova T.M., Kalinichenko G.V. (2011). Research of types of functions of public administration and their importance in the process of state-management activities. Forum rights. No 1. P. 522-527.

18. Ponikarov V.D., Veretelnyk L.K. (2004). Administrative Law: compendium of lectures. 100 p.

19. Malinowski V. Y. (2003). State Administration: taught. 2015- 2015. 567 p.

20. Odintsova G. S., Dziundzyuk V.B., Meltyukhova N. M. and others. (2008). Theory and history of public administration: teaching. the posibn. 288 p.

21. Melnyk A. F. (2003). Public Administration. 343 p.

22. Yevtushenko O.N., Andriyash V.I. (2013). State Administration (Fundamentals of Theory of Public Administration). $268 \mathrm{p}$.

23. Osovska G.V. (2003). Basics of management: taught. 2015- 2015 for studs. higher teachings. 556 p. 